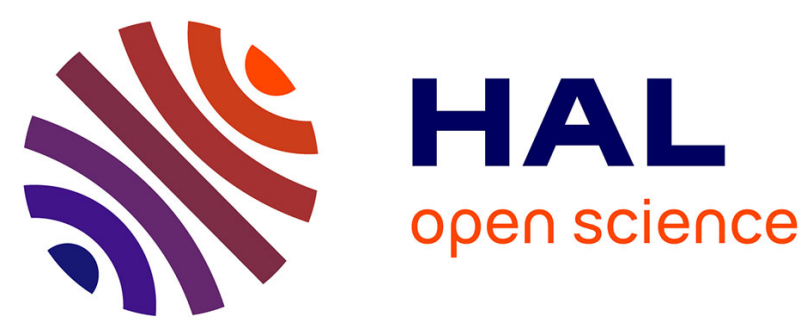

\title{
Relationship between phytoplankton efficiency and the proportion of bacterial production to primary production in the Mediterranean Sea
}

P. Conan, C. Turley, E Stutt, Mireille Pujo-Pay, France van Wambeke

\section{- To cite this version:}

P. Conan, C. Turley, E Stutt, Mireille Pujo-Pay, France van Wambeke. Relationship between phytoplankton efficiency and the proportion of bacterial production to primary production in the Mediterranean Sea. Aquatic Microbial Ecology, 1999, 17 (2), pp.131-144. 10.3354/ame017131 . hal01829903

\section{HAL Id: hal-01829903 \\ https://hal.science/hal-01829903}

Submitted on 4 Jul 2018

HAL is a multi-disciplinary open access archive for the deposit and dissemination of scientific research documents, whether they are published or not. The documents may come from teaching and research institutions in France or abroad, or from public or private research centers.
L'archive ouverte pluridisciplinaire HAL, est destinée au dépôt et à la diffusion de documents scientifiques de niveau recherche, publiés ou non, émanant des établissements d'enseignement et de recherche français ou étrangers, des laboratoires publics ou privés. 


\title{
Relationship between phytoplankton efficiency and the proportion of bacterial production to primary production in the Mediterranean Sea
}

\author{
P. Conan ${ }^{1, *}$, C. Turley $^{2}$, E. Stutt ${ }^{2}$, M. Pujo-Pay ${ }^{3}$, F. Van Wambeke ${ }^{4}$ \\ ${ }^{1}$ Centre d'Océanologie de Marseille, OSU-LOB, UMR6535, Campus de Luminy, Case 901, F-13288 Marseille Cedex 09, France \\ ${ }^{2}$ Plymouth Marine Laboratory, Citadel Hill, Plymouth PL1 2PB, United Kingdom \\ ${ }^{3}$ Laboratoire d'Océanographie Biologique, laboratoire Arago, BP 44, F-66651 Banyuls-sur-Mer Cedex, France \\ ${ }^{4}$ Laboratoire de Microbiologie Marine, CNRS case 907, Campus de Luminy, F-13288 Marseille Cedex 09, France
}

\begin{abstract}
Biomass and production of phytoplankton and heterotrophic bacteria were measured during July 1995 along 3 onshore-offshore transects in the NW Mediterranean Sea (Gulf of Lions). The trophic status of the investigated stations varied from weakly oligotrophic to mesotrophic. Two distinct groups of stations were separated when examining the relationships between primary producers, bacteria and nutrients. The 2 groups of stations exhibited a different relationship between the ratio of integrated bacterial production to integrated primary production (IBP/IPP) and IPP. However, there was no longer a difference between the 2 groups when taking into account the phytoplankton efficiency (PE; i.e. IPP in $\mathrm{mg} \mathrm{C} \mathrm{m} \mathrm{m}^{-2} \mathrm{~h}^{-1}$ divided by integrated chlorophyll in $\mathrm{mg} \mathrm{m}^{-2}$ ) instead of IPP. Indeed, the most striking feature was a highly significant power fit of IBP/IPP versus PE, for a larger set of data collected in the Mediterranean Sea despite large differences in location, season, physical structure, nutrient and biological status of the stations (IBP/IPP $=25.1 \mathrm{PE}^{-068}$ ). For a large range of PE (i.e. higher than $1.0 \mathrm{mg} C$ $\mathrm{mg}^{-1} \mathrm{chl} \mathrm{h}^{-1}$ ) the ratio remained below $25 \%$, but increased dramatically for lower values of PE. This relationship may help to explain the considerable variation ( 2 to $190 \%$ ) in bacterial production/primary production ratio previously found in the world's oceans.
\end{abstract}

KEY WORDS: Phytoplankton - Bacteria - Primary production - Bacterial production - Phytoplankton efficiency Productivity

\section{INTRODUCTION}

The Mediterranean Sea is characterised by 2 different systems as described by Thingstad \& Rassoulzadegan (1995). The first occurs in winter, in frontal zone or upwelling areas and is characterised by a high new production, large organisms and high sedimentation rates due to the presence of large particles. In the second system, which occurs during summer and in offshore waters, phosphate is a limiting factor for phytoplankton and bacterial growth. It is characterised by small organisms and a storage of carbon, nitrogen and maybe phosphorus in dissolved organic forms, exported at the end of the stratification period (Copin-

•E-mail: conan@com.univ-mrs.fr
Montégut \& Avril 1993, Conan 1996, Conan et al. 1998). The capacity of autotrophic organisms to fix inorganic carbon could be achieved by considering the phytoplankton efficiency (PE), defined as the ratio between primary production and chlorophyll concentration (Parsons et al. 1984). In saturating light conditions, this ratio is also named the 'assimilation number'. Although the chlorophyll concentration of a cell is extremely variable, this ratio could be approximated as an index of the physiological state of phytoplankton. The PE varies with species and/or environmental and trophic conditions (Le Bouteiller \& Herbland 1984, Schiewer 1984, Videau et al. 1994). Indeed, values of $\mathrm{PE}$ in cultures of different algae lie in the range from 1 to $21 \mathrm{mg} \mathrm{C} \mathrm{mg}^{-1} \mathrm{chl} \mathrm{h}^{-1}$ or even from 0.1 to $35.0 \mathrm{mg} \mathrm{C}$ $\mathrm{mg}^{-1} \mathrm{chl} \mathrm{h}^{-1}$ in natural populations of phytoplankton. 
Maximum values of PE were measured in coastal waters of temperate and low latitudes whereas minimum values came from high latitudes and from oligotrophic areas.

The role of the microbial food web (Azam et al. 1983) in the regulation of carbon transfer is important (Joiris et al. 1982, Keller \& Riebesell 1989, Ducklow \& Carlson 1992, Christaki \& Van Wambeke 1995) and must be considered to better define mass budgets (Kirchman et al. 1992, Bronk et al. 1994, Pujo-Pay et al. 1997). In the euphotic zone, the proportion of primary production required to support bacterial production (BP/PP ratio) varies from 2 to $190 \%$ (Ducklow \& Carlson 1992) and is around $40 \%$ in most environments (Cole et al. 1988). Such variations remain largely unexplained. In terms of budgets, bacteria are generally considered as a weak or even zero exportation vector of matter (Ducklow et al. 1986, Sherr et al. 1987).

Dissolved organic matter becomes available for bacterial utilisation through phytoplankton exudation and lysis, grazing and release by zooplankton and also by physical disaggregation of detrital particles. The origin and the coupling between sources of phytoplanktonderived material and its consumption by bacteria play a main role in the variability of the $\mathrm{BP} / \mathrm{PP}$ ratio. Dissolved organic carbon (DOC; Larsson \& Hagström 1982), nitrogen (DON; Jørgensen et al. 1993, Pujo-Pay et al. 1997) and phosphorus (DOP; Jackson \& Williams 1985) originating from phytoplankton are important controls in bacterial growth (Azam et al. 1993). Due to their high affinities for nutrients, their high surface area/biovolume ratios, their low N/P ratios ( $9 / 1)$, bacteria can sequester particulate nitrogen and phosphorus. Bacteria may also compete with phytoplankton for key nutrients such as phosphate or nitrate (Kirchman et al. 1992). Jansson (1988) argues that an increase in DOC release by phosphate-limited phytoplankton is induced by the competition against bacteria for phosphate. This kind of relationship could be particularly important in the Mediterranean (impoverished in phosphate), where grazing rates which may balance the system (Thingstad \& Rassoulzadegan 1995) remain high throughout the year (Lefèvre et al. 1997).

Here we explore a potential phytoplankton-bacterial relationship through the rate of primary production and bacterial production and through their ratio. This study takes place in the Gulf of Lions (NW Mediterranean Sea), where there is large scale variability in productivity from oligotrophy to mesotrophy (Conan et al. 1998). We compare these potential relationships with other Mediterranean data available from the literature and from other sources (unpubl. data). We also discuss the mechanisms that could regulate the partitioning of fluxes of primary production between the microbial and the metazoan food web.

\section{METHODS}

Primary production, chlorophyll and nutrient concentrations, bacterial biomass and production rates were measured and related to the physical structure of the water column at stations along 3 onshore-offshore transects in the NW Mediterranean (Fig. 1, Table 1) during a cruise from 30 June to 6 July 1995 on the RV 'Suroit'.

Sample collection. Physical parameters were measured with a CTD probe (Seabird 911+) coupled to a electronically operated rosette of 81 volume Niskin bottles for taking seawater samples. All the production casts were carried out before sunrise.

Nutrients. Subsamples of $10 \mathrm{ml}$ were taken in a polyethylene scintillation vial and immediately frozen at $-20^{\circ} \mathrm{C}$. On land, unfiltered samples were rapidly thawed and analysed for nitrate $\left(\mathrm{NO}_{3}\right.$, standard error $0.1 \mu \mathrm{M})$, nitrite $\left(\mathrm{NO}_{2}\right.$, standard error $\left.0.02 \mu \mathrm{M}\right)$ and phosphate $\left(\mathrm{PO}_{4}\right.$, standard error $\left.0.02 \mu \mathrm{M}\right)$ according to classical methods on an automated Technicon analyser (Strickland \& Parsons 1972, adapted by Tréguer \& Le Corre 1975)

Nitrate and phosphate vertical turbulent diffusion were calculated by the formula $F=K_{v} \mathrm{~d} c / \mathrm{d} z$ where $\mathrm{d} c / \mathrm{d} z$ is the vertical nutrient gradient and $K_{v}$ is the turbulent diffusion coefficient (Denman \& Gargett 1983).

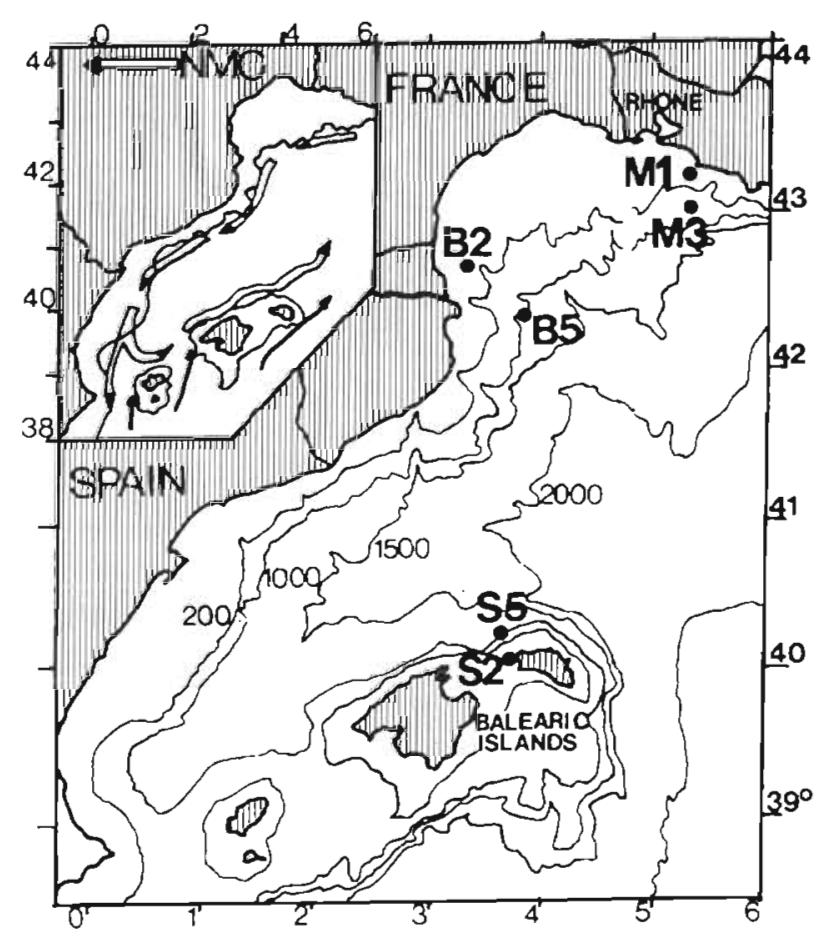

Fig. 1. Map of NW Mediterranean Sea showing the station positions along the 3 transects sampled during the Euromarge cruise. NMC is the North Mediterranean Current (general circulation of the area) which is shown in the insert 
Table 1. Sampling dates, location and water depth of stations sampled during the Euromarge cruise

\begin{tabular}{|lccr|}
\hline $\begin{array}{l}\text { Station } \\
\text { no. }\end{array}$ & $\begin{array}{c}\text { Sampling } \\
\text { date (1995) }\end{array}$ & $\begin{array}{c}\text { Position } \\
\text { (lat./long.) }\end{array}$ & \multicolumn{1}{c|}{$\begin{array}{c}\text { Depth } \\
\text { (m) }\end{array}$} \\
\hline B5 & 30 Jun & $42^{\circ} 24.0^{\prime} \mathrm{N}, 3^{\circ} 44.0^{\prime} \mathrm{E}$ & 1000 \\
B2 & 1 Jul & $42^{\circ} 340^{\prime} \mathrm{N}, 3^{\circ} 17.0^{\prime} \mathrm{E}$ & 88 \\
S5 & 2 Jul & $40^{\circ} 9^{\prime} 5^{\prime} \mathrm{N}, 3^{\circ} 31.5^{\prime} \mathrm{E}$ & 970 \\
S2 & 3 Jul & $40^{\circ} 2.0^{\prime} \mathrm{N}, 3^{\circ} 380^{\prime} \mathrm{E}$ & 120 \\
M3 & 5 Jul & $43^{\circ} 2.0^{\prime} \mathrm{N}, 5^{\circ} 12.5^{\prime} \mathrm{E}$ & 950 \\
M1 & 6 Jul & $43^{\circ} 10.0^{\prime} \mathrm{N}, 5^{\circ} 12.5^{\prime} \mathrm{E}$ & 85 \\
\hline
\end{tabular}

$K_{\mathrm{v}}$ was calculated from $0.25 \varepsilon\left(1 / N^{2}\right)$ where $N^{2}=(g / \rho \omega)$ $(\mathrm{d} \rho / \mathrm{d} z), \varepsilon$ is the dissipation of the turbulent energy, $N$ is the stratification coefficient, $g$ is the gravitational acceleration, $\rho$ is the density, $\omega$ is the earth angular rotating speed and $\mathrm{d} \rho / \mathrm{d} z$ is the density gradient. We use a $\varepsilon$ of $10^{-8} \mathrm{~m}^{2} \mathrm{~s}^{-3}$ (Dillon \& Caldwell 1980), which results in a $K_{\mathrm{v}}$ falling in the broad range between 1.5 and $3.9 \times 10^{-5} \mathrm{~m}^{-2} \mathrm{~s}^{-1}$ for our stations. This is in agreement with the calculated range for this area given by Minas \& Codispoti (1993).

Chlorophyll and primary production. Chlorophyll concentration was analysed according to the fluorimetric method (Holm-Hansen \& Riemann 1978) using a Turner Designs 10.005R fluorimeter, after filtration of $250 \mathrm{ml}$ of subsample onto a Whatman GF/F $25 \mathrm{~mm}$ filter.

The assessment of primary production (PP) using ${ }^{14} \mathrm{C}$ (Steemann-Nielsen 1951) was carried out from dawn to dusk (10 to $12 \mathrm{~h}$ ) by using a new semi-automated in situ apparatus called Let-go (Dandonneau \& Le Bouteiller 1992, Conan 1996). On deployment, this system takes 15 water samples (about $250 \mathrm{ml}$ ) at predefined depths and automatically injects $1 \mathrm{ml}$ of radiolabelled solution ( $\mathrm{NaH}^{14} \mathrm{CO}_{3}=25 \mu \mathrm{Ci}$ ). The incubation chambers are made of transparent or black polymethacrylate for measurements of light and dark carbon fixation, respectively. At the end of the incubation, the Let-go is hauled onboard and the samples are transferred into clean dark bottles, previously washed for $72 \mathrm{~h}$ with $0.5 \mathrm{M} \mathrm{HCl}$ and carefully rinsed many times with deionised water. Total introduced radioactivity $\left(\mathrm{dpm}_{1}\right)$ was measured after incubation by placing $250 \mu$ of sample in a polyethylene scintillation vial with $250 \mu \mathrm{l}$ of ethanolamine and $1 \mathrm{ml}$ of deionised water. Each sample was then immediately filtered onto a Whatman GF/F filter (25 mm diameter) under low pressure ( $<5 \mathrm{~mm} \mathrm{Hg}$ ), rinsed with $500 \mu$ of $0.5 \mathrm{M} \mathrm{HCl}$ and dried at $40^{\circ} \mathrm{C}$ for $12 \mathrm{~h}$. Dried filters were stored at ambient temperature. On land, samples were counted $\left(\mathrm{dpm}_{2}\right)$ in a Beckman Scintillation Counter after the addition of $10 \mathrm{ml}$ of scintillation cocktail solution (Aquasol). The quantity of fixed carbon per hour (PP in mg $\mathrm{C} \mathrm{m}^{-3} \mathrm{~h}^{-1}$ ) was calculated using the formula $\mathrm{PP}=$ $\left(\mathrm{dpm}_{2} / \mathrm{dpm}_{1}\right)\left(V_{\mathrm{p}} / V_{\mathrm{f}}\right) A 1.05(1 / t)$, where $V_{\mathrm{p}}$ is the volume of sample taken for determination of total radioactivity, $V_{1}$ is the volume of sample, $A$ is the concentration of carbonates in seawater (about $25000 \mathrm{mg} \mathrm{C} \mathrm{m}^{-3}$ ), 1.05 is the isotopic fractionation between ${ }^{12} \mathrm{C}$ and ${ }^{14} \mathrm{C}$ and $t$ is the incubation time expressed in hours. Daily production rates were estimated by $P P \times 12$. The phytoplankton efficiency (PE) is defined as the ratio between $\mathrm{PP}$ and chlorophyll concentration, $\mathrm{PP} / \mathrm{CHL}$,

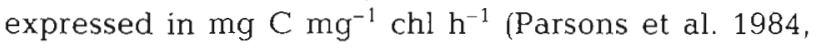
Falkowski \& Woodhead 1992). In this paper, we also use a derived ratio, i.e. for integrated quantities (IPP/ICHL).

Bacterial abundance and biomass. Bacteria were enumerated by a direct count method using epifluorescent microscopy and the DAPI fluorochrome (Porter \& Feig 1980). After preserving the samples in $0.2 \mu \mathrm{m}$ pore size filtered $2 \%$ glutaraldehyde (final volume), they were sonicated on ice for $60 \mathrm{~s}$ on a $50 \%$ on-off cycle at $75 \mathrm{~W}$ on a Vibracell $20 \mathrm{kHz}$ ultrasonicator, which ensured the dispersion of cells without disruption. An appropriate volume (to ensure 20 to 30 cells per field) of sample was stained with $0.2 \mu \mathrm{m}$ filtered DAPI solution (1 $\mathrm{mg} \mathrm{l}^{-1}$ final concentration) for $10 \mathrm{~min}$ before filtering onto a black $0.2 \mu \mathrm{m}$ pore size Nuclepore filter. The filter was mounted on a slide with nonfluorescent immersion oil and a coverslip and was stored frozen until enumeration on land. The standard error for 3 replicates from 30 and $60 \mathrm{~m}$ depth was 10.3 and $10.2 \%$, respectively. This whole procedure was carried out at sea to ensure that we did not underestimate cell numbers because of the dramatic loss of epifluorescent detectable bacteria that has been found during storage of the fixed seawater samples from the NE Atlantic (Turley \& Hughes 1992, 1994, Vosjan \& Van Noort 1998). Similar losses were observed in seawater samples from the Mediterranean (C. Turley pers. obs.), confirming the need to carry out sample preservation, staining, filtering and mounting on slides procedure at sea, shortly after sampling.

Bacterial biomass ( $\mathrm{BB}$ ) was calculated from the numbers of bacteria and the relatively constant cell to carbon values (with a mean around $20 \mathrm{fg} \mathrm{C} \mathrm{Cell}^{-1}$ ) for natural free-living bacterial assemblages (Lee \& Fuhrman 1987).

Measurement of bacterial protein synthesis. Protein synthesis was determined by the incorporation of ${ }^{3} \mathrm{H}-$ leucine into trichloroacetic acid (TCA) insoluble macromolecular material (Kirchman 1993). The amounts of ${ }^{3} \mathrm{H}$-leucine incorporation into the cold TCA insoluble material are generally not significantly different to the hot TCA insoluble material (Chin-Leo \& Kirchman 1988 ) in aquatic samples. We therefore used the icecold extraction method for greater convenience for use 
at sea. Three $5 \mathrm{ml}$ replicates from each depth received $10 \mathrm{nM}^{3} \mathrm{H}$-leucine (final concentration). One of the replicates had already received glutaraldehyde $(2 \%$ final concentration) and acted as the dead control. Samples were incubated in the dark at in situ temperatures for a predetermined period ( 2 to $5 \mathrm{~h}$ ) which lies in the linear period of incorporation. After this period the live incubations were terminated with glutaraldehyde and all samples were filtered onto $0.2 \mu \mathrm{m}$ pore size $25 \mathrm{~mm}$ diameter Nuclepore filters and extracted in the filter tower with $5 \%$ ice-cold TCA for 5 min followed by five $1 \mathrm{ml}$ rinses with $5 \%$ ice-cold TCA. Filters were placed in scintillation vials; when dry, $5 \mathrm{ml} \mathrm{Beck-}$ man Ready Safe scintillation cocktail was added and their radioactivity counted on a Beckman LS 1800 liquid scintillation counter. Counting efficiency was corrected for quenching by the external standard channels ratio method. The standard error calculated from the replicates ranged between 1.8 and $7.4 \%$ with a mean standard error for this cruise of $4.1 \%$. On a previous cruise in the NW Mediterranean, we found no difference in ${ }^{3} \mathrm{H}$-leucine incorporation rate between additions of 5 or $10 \mathrm{nM}{ }^{3} \mathrm{H}$-leucine (final concentration). We therefore felt justified that the addition of $10 \mathrm{nM}$ on this cruise more than ensured that kinetic saturation of leucine uptake was achieved (Turley et al. 1996).

Rates of bacterial production (BP) were calculated from leucine incorporation rates using a conversion factor of $0.15 \times 10^{18}$ cells $\mathrm{mol}^{-1}$ leucine (Bjørnsen \& Kuparinen 1991) and $20 \mathrm{fg} \mathrm{C}$ cell $^{-1}$ (Lee \& Fuhrman 1987). This is the same as the conversion factor of $3.1 \mathrm{~kg} \mathrm{C} \mathrm{mol}{ }^{-1}$ recommended by Kirchman (1993) which is based on the following best estimates: an isotope dilution of 2 , a ratio of cellular carbon to protein of 0.86 and the fraction of leucine in protein of 0.073 . Daily BP was calculated as $24 \times$ hourly BP.

Statistical analysis. All the integrated values are deduced according the classical trapezoidal method. Principal Component Analysis (PCA) was carried out on 26 independent variables, taken from the upper $80 \mathrm{~m}$ where much of the variation occurred, from each station in order to demonstrate relationships between stations and to assess covariance between variables which may explain any separation or grouping of stations. The variables describe the hydrological and biotic conditions in this dynamic part of the water column and were standardised to zero mean and unit variance. On the basis of the PCA analysis, the data from the upper $80 \mathrm{~m}$ was split into 2 groups of stations and analysis of variance (ANOVA) was used to test for significant differences between variables. Multiple linear regression analysis of the 2 data sets representing the 2 groups of stations was also carried out in order to see if they contained key variables which could explain much of the total variability (Conan et al. unpubl.).

\section{RESULTS}

The 3 transects (Fig. 1) are fully described in Conan et al. (unpubl.). Here, we only illustrate each station (Fig. 2) by vertical profiles of salinity, phosphate $\left(\mathrm{PO}_{4}\right)$, chlorophyll concentration ( $\mathrm{CHL}$ ), bacterial biomass (BB), primary production (PP) and bacterial production (BP). On each transect, 1 station is representative of a coastal situation (B2, S2, M1) whereas the other station is representative of an offshore situation (B5, S5, M3). The Banyuls transect (Fig. 2a) is characterised by low surface salinity $(<36.5)$ at Stn B5, which clearly indicates continental freshwater inputs. The weak surface increase (Fig. 2a) in CHL $\left(0.8 \mathrm{mg} \mathrm{m}^{-3}\right), \mathrm{BB}(16.0 \mathrm{mg} \mathrm{C}$ $\left.\mathrm{m}^{-3}\right)$, phosphate $(\sim 0.1 \mu \mathrm{M})$ and the high PP $(\sim 70 \mathrm{mg} \mathrm{C}$

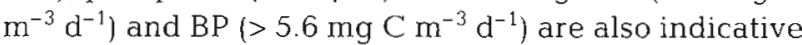
of the Rhône river influence (Lefèvre et al. 1997). Contrary to the other transects (Fig. $2 \mathrm{~b}, \mathrm{c}$ ), the Banyuls one is characterised by detectable phosphate concentrations $(\sim 0.05 \mu \mathrm{M})$ over the whole water column (Fig. 2a).

Along the Balearic transect, a well-stratified water column is encountered. Indeed, a sharp increase in salinity (from $<37.50$ to $>38.00$ ) is observed between 20 and $50 \mathrm{~m}$ at both stations (Fig. 2b). This indicates a clear 2-layered system with a surface water layer originating from the Atlantic via the Strait of Gibraltar up to a Mediterranean water layer. Such an injection of Atlantic water between the Balearic islands is common at this time (Millot 1987). Nutrients are depleted down to $50 \mathrm{~m}$ at these 2 stations. The $\mathrm{CHL}$ distributions showed a well-defined deep chlorophyll maximum (DCM) at $60 \mathrm{~m}\left(1.2 \mathrm{mg} \mathrm{m}^{-3}\right)$. The same relative pattern is observed for $\mathrm{BB}$ but with concentrations also high in surface water (10 to $16 \mathrm{mg} \mathrm{C} \mathrm{m}{ }^{-3}$ ) with a peak at $40 \mathrm{~m}$ for Stn S5 (Fig. 2b). PP was relatively low in surface water $\left(6\right.$ and $10 \mathrm{mg} \mathrm{C} \mathrm{m}^{-3} \mathrm{~d}^{-1}$ at Stns S5 and S2 respectively) and then decreased gradually before a secondary weak peak at $60 \mathrm{~m}$, coinciding with the DCM ( 4 and $10 \mathrm{mg} \mathrm{C} \mathrm{m}^{-3} \mathrm{~d}^{-1}$ at Stns S5 and S2 respectively). $\mathrm{BP}$ was also highest in the upper mixed layer (1.6 to $2.4 \mathrm{mg} \mathrm{C} \mathrm{m}^{-3} \mathrm{~d}^{-1}$ ), decreasing to $0.2 \mathrm{mg} \mathrm{C} \mathrm{m}^{-3} \mathrm{~d}^{-1}$ at $100 \mathrm{~m}$.

The 2 Stns M1 and M3 offshore of Marseilles (Fig. 1) were characterised by salinity close to 38.00 (Fig. 2c), typical of Modified Atlantic Water (Millot 1987, Conan \& Millot 1995). Stn M3 had low nutrient concentrations down to $100 \mathrm{~m}(<0.03 \mu \mathrm{M}$ in phosphate) whereas the phosphacline appeared at $60 \mathrm{~m}$ for Stn M1. CHL distributions were characterised by a large peak over the superficial water layer (with a maximum of about $0.8 \mathrm{mg} \mathrm{m}^{-3}$ at $80 \mathrm{~m}$ for Stn $\mathrm{M} 3$ and $50 \mathrm{~m}$ for Stn M1). BB 
a)
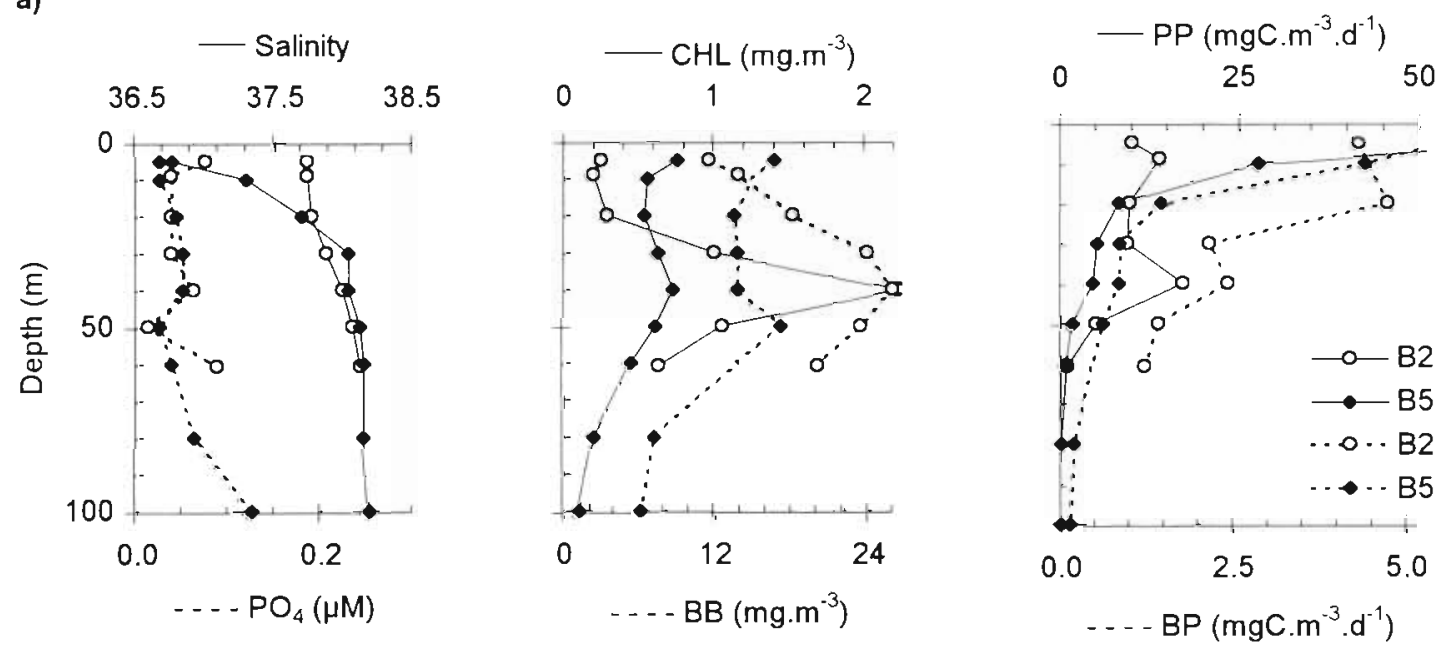

b)
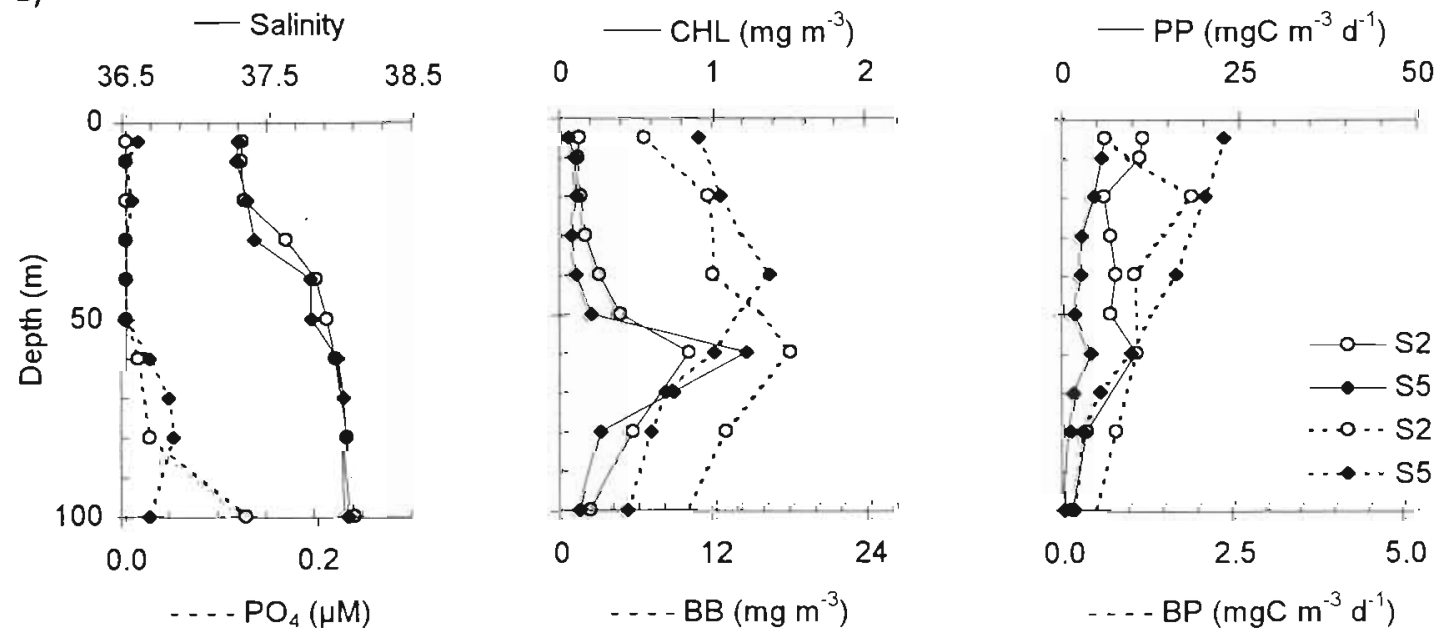

c)
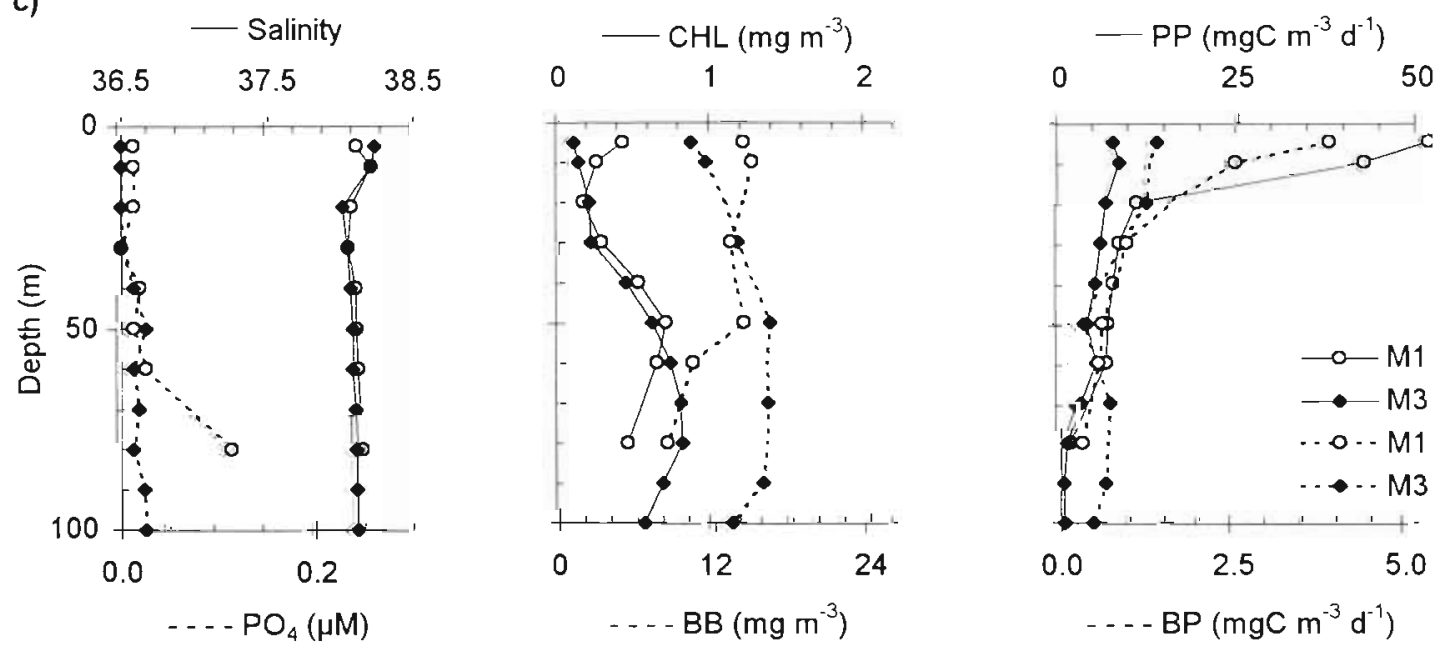

Fig. 2. Vertical profiles of salinity, phosphate $\left(\mathrm{PO}_{4}\right.$ in $\left.\mu \mathrm{M}\right)$; chlorophyll $\left(\mathrm{CHL}\right.$ in $\left.\mathrm{mg} \mathrm{m}^{-3}\right)$, bacterial biomass (BB in $\left.\mathrm{mg} \mathrm{m}^{-3}\right)$; primary

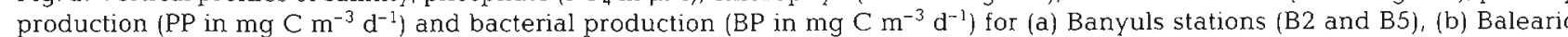
stations (S2 and S5) and (c) Marseilles stations (M1 and M3) sampled during 30 June to 6 July 1995 on the Euromarge cruise 
was quite homogeneous in the euphotic zone (10 to $16 \mathrm{mg} \mathrm{C} \mathrm{m}{ }^{-3}$ ). PP ( 4 to $8 \mathrm{mg} \mathrm{C} \mathrm{m}^{-3} \mathrm{~d}^{-1}$ ) and BP (0.3 to $1.4 \mathrm{mg} \mathrm{C} \mathrm{m}^{-3} \mathrm{~d}^{-1}$ ) were homogeneous and low at Stn $M 3$, but showed a pronounced surface peak at Stn M1 (43 to $52 \mathrm{mg} \mathrm{C} \mathrm{m}{ }^{-3} \mathrm{~d}^{-1}$ for PP and 2.5 to $4.0 \mathrm{mg}$ $\mathrm{C} \mathrm{m}^{-3} \mathrm{~d}^{-1}$ for BP)

\section{Statistical separation of stations}

A wide range of environmental conditions were observed during the cruise as illustrated in Fig. 2. This is confirmed by the statistical analysis of the data set, carried out in Conan et al. (unpubl.). The main author's conclusion is that the stations separate into 2 distinct groups (see text in Fig. 3a,b). The first 2 principal components of the PCA (principal component analysis) account for $72 \%$ of the total variance. The first component, which accounts for virtually half the variance, separates Stns M1, B5 and B2 (Group 1) from Stns M3, S2 and S5 (Group 2).

The PCA confirms that stations from Group 1 (i.e. M1, B5, B2) had a shallow nitracline, higher salinity and high PP but not a corresponding proportional increase in variables related to bacteria (BP, BB) and richness (nutrients, CHL). In contrast, Stns S2, S5, and

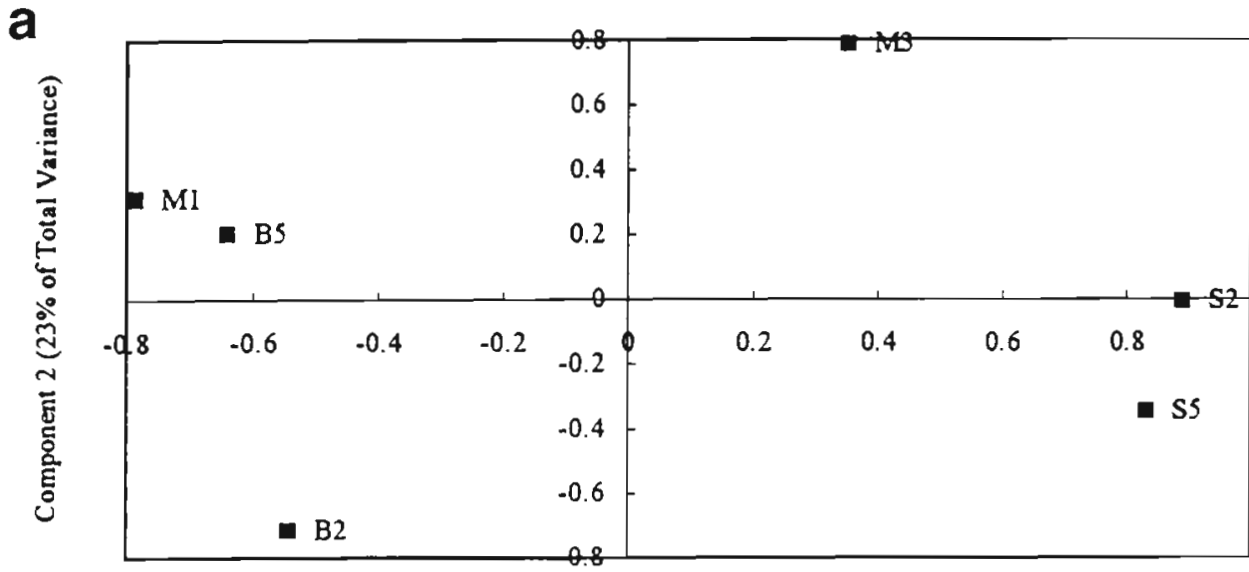

Component 1 ( $49 \%$ of Total Variance)

b

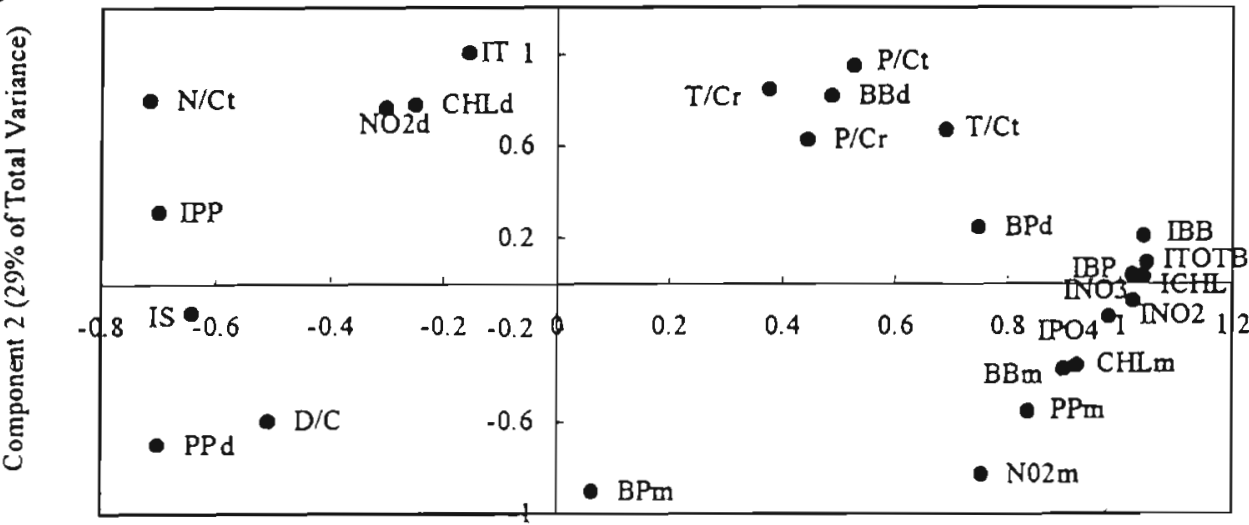

Component 1 ( $47 \%$ of Total Variance)

Fig. 3 (extracted from Conan et al. unpubl.). Principal component analysis (PCA) of 26 independent variables measured in the upper $80 \mathrm{~m}$ of each station on the Euromarge cruise (a) to demonstrate relationships between stations and (b) to assess covariance between variables. Variables were standardised to zero mean and unit variance. Variables used were: top of thermocline $(\mathrm{T} / \mathrm{Ct})$, bottom of thermocline ( $\mathrm{T} / \mathrm{Cr})$, top of pycnocline $(\mathrm{P} / \mathrm{Ct})$, bottom of pycnocline $(\mathrm{P} / \mathrm{Cr})$, top of nitracline $(\mathrm{N} / \mathrm{Ct})$, delta clines $(\mathrm{D} / \mathrm{C})$, which is the difference between top of nitracline and top of phosphacline, maximum concentration of nitrite (NO2m), depth of $\mathrm{NO}_{2}$ maximum (NO2d), chlorophyll concentration at deep chlorophyll maximum (CHLm), depth of deep chlorophyll maximum (CHLd), maximum value of bacterial biomass ( $\mathrm{BBm}$ ), depth of $\mathrm{BBm}$ ( $\mathrm{BBd}$ ), maximum value of primary production (PPm), depth of PPmax (PPd), maximum value of bacterial productivity (BPm), depth of BPmax (BPd), integrated temperature $(0$ to $80 \mathrm{~m}$ ) (IT), integrated salinity (IS), integrated nitrate (INO3), integrated phosphate (IPO4), integrated nitrite (INO2), integrated chlorophyll (ICHL), integrated bacterial biomass (IBB), integrated total biomass (ITOTB), integrated primary production (IPP) and integrated bacterial production (IBP) 
Table 2. Histogram showing the vertical turbulent diffusion fluxes of nitrate and phosphate in the surface layer. Actual values are shown on the left for phosphate and on the right tor nitrate in $\mu \mathrm{mol} \mathrm{m} \mathrm{m}^{-2} \mathrm{~d}^{-1}$

\begin{tabular}{|c|c|c|c|c|c|c|c|c|c|c|c|c|c|c|}
\hline & & \multicolumn{13}{|c|}{ Station } \\
\hline \multicolumn{2}{|c|}{ Diffusion flux } & \multicolumn{2}{|c|}{ M1 } & \multicolumn{2}{|c|}{ B5 } & \multicolumn{2}{|c|}{$\mathrm{B} 2$} & \multicolumn{2}{|c|}{ S5 } & \multicolumn{2}{|c|}{ S2 } & \multicolumn{3}{|c|}{ M3 } \\
\hline \multirow{6}{*}{$\begin{array}{l}\mathrm{PO}_{4} \\
\mathrm{NO}_{3}\end{array}$} & Depth $(m)$ & $\mathrm{PO}_{4}$ & $\mathrm{NO}_{3}$ & $\mathrm{PO}_{4}$ & $\mathrm{NO}_{3}$ & $\mathrm{PO}_{4}$ & NO & $\mathrm{PO}_{4}$ & $\mathrm{NO}_{3}$ & $\mathrm{PO}_{4}$ & $\mathrm{NO}_{3}$ & $\mathrm{PO}_{4}$ & & $\mathrm{NO}_{3}$ \\
\hline & $30 \mathrm{~m}$ & 2 & 14 & & & $2 ?$ & 56 & & & & & & I & \\
\hline & $40 \mathrm{~m}$ & 0 & 119 & & & 0 & 265 & & & & & & - & \\
\hline & $50 \mathrm{~m}$ & 7 & 502 & 2 & 88 & 19 & 1443 & 2 & 110 & 1 ! & 5 & 0 & & \\
\hline & $60 \mathrm{~m}$ & 62 & & 5 & 155 & & & 2 & 119 & 11 & 160 & 0 & & 23 \\
\hline & $80 \mathrm{~m}$ & & 7070 & $27=$ & & & & 0 & 35 & 20 & 330 & 3 & , & 363 \\
\hline
\end{tabular}

to a lesser extent M3, had a deeper nitracline, lower salinity and a more proportional relationship between $\mathrm{PP}$ and variables related to $\mathrm{BP}$ and $\mathrm{BB}$ and most nutrient variables and CHL. The groups of stations are therefore distinguished by their different relationships between PP, heterotrophic production and nutrient concentrations in the upper mixed layer during the sample period.

Another way to illustrate the differences between the 2 groups used by Conan et al. (unpubl.) is to consider the nutrient vertical turbulent diffusion fluxes in the surface layer (Table 2). Group 1 (M1, B5, B2) was characterised by higher fluxes (maximum rates lie from 20 to $60 \mu \mathrm{mol} \mathrm{m} \mathrm{m}^{-2} \mathrm{~d}^{-1}$ in phosphate and from 200 to $1000 \mu \mathrm{mol} \mathrm{m} \mathrm{m}^{-2} \mathrm{~d}^{-1}$ in nitrate) and/or closer to the surface (between 50 and $80 \mathrm{~m}$ ) compared to those of Group 2 (S5, S2, M3). For example, Stns M1 and B2 showed weak diffusion values at $30 \mathrm{~m}$ depth. The deepest maximum flux for Group 1 is calculated for Stn B5, also characterised by non-turbulent diffusion flux up to $50 \mathrm{~m}$, but we have previously described surface Rhône inputs for this station. Finally, the upper layer $(0$ to $50 \mathrm{~m}$ ) of stations in Group 1 received more inorganic nutrients (nitrate and phosphate) than the upper layer of stations in Group 2.

\section{Relationship between primary production and bacterial production}

On a volumetric basis for the euphotic layer, there are highly significant linear relationships ( $p \leq 0.001$ ) between log (BP) and log (PP) in both groups (Fig. 4a). Group 1 has a more extensive range of values for BP and PP than Group 2. However, the 2 relationships are not statistically different and could be combined in a general linear regression (see text in Fig. 4 for further details). This indicates that, despite the statistical sep- aration of the 2 groups by the PCA (i.e. key variables to explain the total variability of the 2 groups are different, Conan et al. unpubl.), there is the same kind of link between PP and BP in the 2 considered groups. This hypothesis is confirmed by the analysis of the $\mathrm{BP} / \mathrm{PP}$ ratio, which is significantly related to $\mathrm{PE}$ by a power relationship (II order: $\mathrm{BP} / \mathrm{PP}=20.89 \mathrm{PE}^{-0.59}, \mathrm{r}^{2}=$ 0.33, $p \leq 0.001$ ) with no longer a difference between the 2 groups (Fig. 4 b). In fact, the power relationship means that there is a relatively constant $\mathrm{BP} / \mathrm{PP}$ ratio (10 to $30 \%$ ) for a wide range of $\mathrm{PE}$ (i.e. for $\mathrm{PE}>0.5 \mathrm{mg} \mathrm{C}$ $\mathrm{mg}^{-1} \mathrm{chl} \mathrm{h}^{-1}$ ). Below this $\mathrm{PE}$ value, the $\mathrm{BP} / \mathrm{PP}$ ratio increases dramatically to reach locally more than $150 \%$.

In terms of integrated quantity (i.e. on an areal basis), the relationships between the IBP/IPP ratio and IPP are different in the 2 groups (Fig. 5). In Group 1 (Stns M1, B5 and B2), IBP/IPP and IPP were linearly related (II order: IBP/IPP $=-0.05 \mathrm{IPP}+60.52, \mathrm{r}^{2}=0.99$, $\mathrm{p} \leq 0.001$ ) while in Group 2 (Stns S2, M3 and S5) they were best fitted by a power relationship (II order: IBP/IPP $=8.5 \times 10^{4} \mathrm{IPP}^{-1.39}, \mathrm{r}^{2}=0.89, \mathrm{p} \geq 0.1 \mathrm{j}$. Both relationships indicate that as IPP decreases, the proportion of IBP to IPP increases. However, the variation is constant in Group 1 regardless of the IPP value, whereas in Group 2, IBP remains between 10 and $20 \%$ of IPP until IPP becomes low (200 to $300 \mathrm{mg} \mathrm{C} \mathrm{m}^{-2} \mathrm{~d}^{-1}$ ). Below this range, the proportion of IBP to IPP increases dramatically (Fig. 5). Hence in the case of mid primary production rates, such as for Stns S2 and B2, a large difference in the IBP/IPP ratio can be seen in the 2 groups. In such a case, the IBP/IPP ratio is more than $30 \%$ in Group 1 compared to about $10 \%$ in Group 2. With respect to the lower and upper limits of the IPP range presented in Fig. 5, we could remark that the IBP/IPP ratios are finally close in the 2 groups ( $-50 \%$ for less than $300 \mathrm{mg} \mathrm{C} \mathrm{m}^{-2} \mathrm{~d}^{-1}$ and $\sim 10 \%$ for more than $1100 \mathrm{mg} \mathrm{C} \mathrm{m}^{-2} \mathrm{~d}^{-1}$ ). 
a)

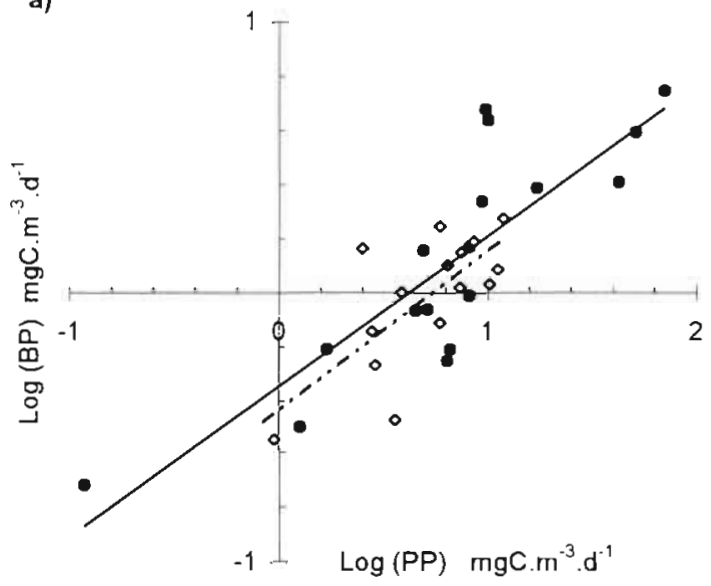

b)

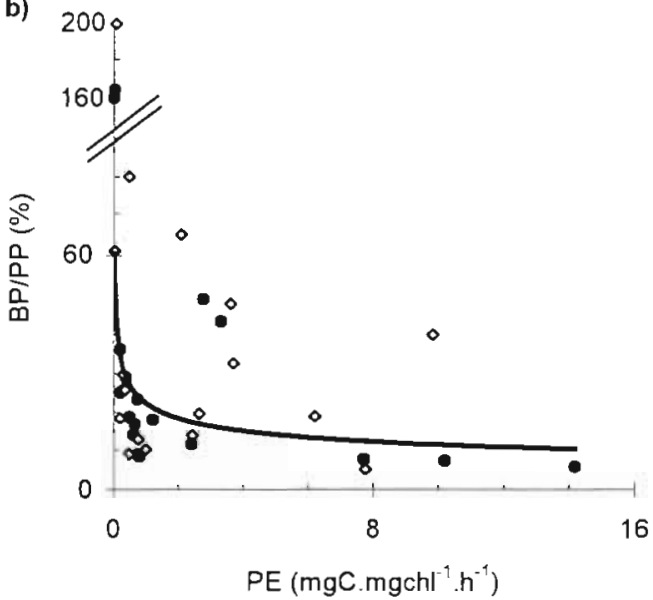

Fig. 4. (a) Plot of log bacterial production (BP) against log primary production (PP) from the upper $80 \mathrm{~m}$ for the $2 \mathrm{groups}$ of stations separated by PCA. (Fig. 3a). The relationship between both these variables is significantly linear in both groups. (•) Data from stations in Group 1 (M1, B5 and B2); (一) linear regression line $\left(\log B P=0.56 \log P P-0.35, r^{2}=0.72, p \leq 0.001\right)$; $(0)$ data from stations in Group $2(S 2, M 3$ and $S 5) ;(---)$ regression line $\left(\log B P=0.60 \log P P-0.44, \mathrm{r}^{2}=0.52, p \leq 0.001\right)$. ANOVA test comparing the 2 lines indicates that there is no statistical difference $\left(F_{2,30}=2.6, p \geq 0.05\right)$ between the 2 regressions. The data from the 2 groups were therefore combined and fitted a linear regression $\left(\log B P=0.57 \log P P-0.39, r^{2}=0.68, p \leq 0.001\right)$. The reduced major axis regression (II order) is $\log \mathrm{BP}=0.64 \log \mathrm{PP}-0.40, \mathrm{r}^{2}=0.68, \mathrm{p} \leq 0.001$. (b) Plot of the ratio of $\mathrm{BP} / \mathrm{PP}$ against the phytoplankton efficiency (PE). A highly significant power relationship (BP/PP $\left.=23.34 \mathrm{PE}^{-0.33}, \mathrm{r}^{2}=0.33, \mathrm{p} \leq 0.001\right)$ was evident with no split between the 2 groups of stations. The reduced major axis regression (II order) was $B P / P P=20.89 \mathrm{PE}^{-0.59}, \mathrm{r}^{2}=0.33, \mathrm{p} \leq 0.001$

\section{DISCUSSION}

\section{Primary production and bacterial production}

Dissolved organic matter originating from phytoplankton is an important substrate for bacterial growth in most marine environments (Larsson \& Hagström 1982, Azam et al. 1993, Pujo-Pay et al. 1997), especially in systems with reduced external influence as in open ocean case. However, the true proportion of matter originating from $\mathrm{PP}$ used to support $\mathrm{BP}$ is generally unknown and nearly impossible to measure directly. This is explained by the difficulty in separating the various sources used by heterotrophic bacteria for their growth and/or by the difficulty in quantifying accurately the phytoplankton release, which is known to vary from about 0 to more than $80 \%$ of PP depending on physiological and environmental conditions (Myklestad 1977, Wood \& Van Valen 1990) and with algal or bacterial assemblages (Malinsky-Rushansky \& Legrand 1996). It is therefore common to consider the $\mathrm{BP} / \mathrm{PP}$ ratio to characterise a potential flux between the bacterial and phytoplankton compartment (Ducklow \& Carlson 1992). However, PP and BP are not necessarily coupled on the time-scale and/or space-scale of the observations (Azam et al. 1993, Kirchman et al. 1995).

During the Euromarge cruise, the encountered hydrological and meteorological conditions were stable and typical for that area at that time (Millot 1987. Conan \& Millot 1995, Conan 1996, Conan et al. 1998).
In the 'Results' section, we have seen that the factors which controlled PP and BP could be the same in the 2 groups defined by the PCA (Fig. $4 \mathrm{a}, \mathrm{b}$ ) but they must have acted in a different way to explain a linear relationship in Group 1 and a power relationship in Group 2 between the IBP/IPP ratio and IPP (Fig. 5). In order to provide a better overview, we compared the observed relationships with those found in the literature (Table 3). When considering the bacterial and phytoplankton biomass, a broad range of values were found in the different studies (Table 3: Simon et al. 1992, Lochte et al. 1997, this study). On the contrary, when considering the production on a volumetric basis, we found a weak range of values for the slope and the $y$ intersection of the linear regression, 0.6 to 0.8 and -0.2 to -0.5 respectively (Table 3: Cole et al. 1988, Del Giorgio et al. 1997, Lochte et al. 1997, this study). More obvious on an areal basis, the same relationship was found in this study and by Cole et al. (1988). A weak range was also defined for the oceanic sample in this study and by Hoch \& Kirchman (1993) with respect to the slope of the linear regression $(0.5$ to 0.7$)$. In fresh water, this last range could be slightly higher $(>0.9$, Table 3).

The PP, BP, CHL and $\mathrm{BB}$ distributions clearly indicate higher maximum values located closer to the surface in Group 1 than in Group 2 (Fig. 2). These key variables revealed a trophic gradient between the 2 groups. In Group 2, stations were characterised by more pronounced oligotrophy than those of Group 1 . 


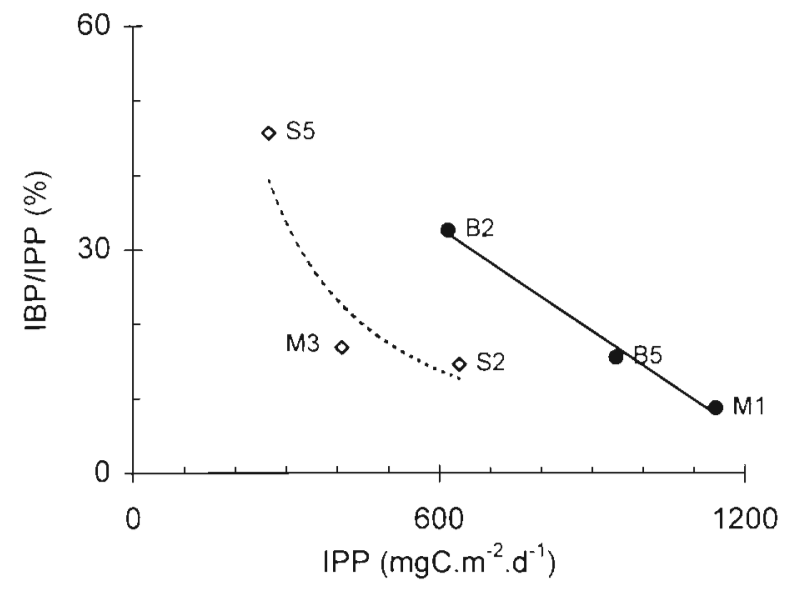

Fig. 5. Plot of the ratio of integrated BP/integrated PP (i.e. IBP/IPP) against IPP for the 2 groups of stations. (•) Data from Group 1 (Stns M1, B5 and B2), which best fit a linear regression line $(-)\left(\mathrm{IBP} / \mathrm{IPP}=-0.05 \mathrm{IPP}+60.59, \mathrm{r}^{2}=0.99, \mathrm{p} \leq 0.001\right.$, or for the reduced major axis regression: IBP/IPP $=-0.05 \mathrm{IPP}+$ $60.52, r^{2}=0.99, p \leq 0.001$ ). ( $(\diamond)$ Data from Group 2 (Stns S2, M3 and S5), which best fit a power regression (...) IBP/IPP = $5 \times 10^{4} \mathrm{IPP}^{-1.28}, \mathrm{r}^{2}=0.89, \mathrm{p} \leq 0.100$ or $\mathrm{IBP} / \mathrm{IPP}=8.5 \times 10^{4}$ IPP-1.39, $\mathrm{r}^{2}=0.89, \mathrm{p} \leq 0.100$ for the reduced major axis regression

which could be considered as mesotrophic stations. Indeed, there is some evidence that stations in Group 1 received more nutrient inputs than those in Group 2, via turbulent vertical diffusive processes (Table 2), from bottom and/or from coastal influence (Fig. 1). Stns M1 and B2 were less than $90 \mathrm{~m}$ deep (Table 1) and Stn B5 received Rhône river inputs (Fig. 2). These addi- tional nutrient inputs certainly explain the wide observed range of PP (Fig. 4) and the higher variability of the BP/PP ratio in Group 1. For Stns S2, S5 and M3, the nutrients originate only from a relatively weak and deep turbulent vertical diffusion (Table 2) and from regenerative processes. So, phytoplankton and bacteria need to compete for nutrients.

Only few data are available in the Mediterranean Sea concerning simultaneous estimates of PP and BP. Those we have found have been included in Fig. 6a They fit into the 2 relationships already defined in Fig. 5, with little change in the regression formula and statistics (Group 1: IBP/IPP $=-0.04 \mathrm{IPP}+57.50$; Group 2: IBP/IPP $=882.5 \mathrm{IPP}^{-0.67}$ ). In Fig. $6 \mathrm{a}$, the stations coming from the Algerian basin could not be integrated in any regressions. However, the differences between the 2 groups of stations and even the unexpected high ratios of the stations from the Algerian basin disappear on considering the relationship between the IBP/IPP ratio and the phytoplankton efficiency (PE), also named 'assimilation number', in optimum light conditions (Fig. 6b). There is a highly significant power relationship between these 2 physiological variables $\left(\mathrm{IBP} / \mathrm{IPP}=25.1 \mathrm{PE}^{-0.68}, \mathrm{r}^{2}=0.71, \mathrm{p} \leq 0.001\right)$.

Thus, despite large differences in location, season and/or physical, nutrient and biological status of the stations, a close relationship could be found between IBP and the physiological state of the phytoplankton. This relationship indicates that when phytoplankton are efficient in carbon production (i.e. $\mathrm{PE} \geq 1.5 \mathrm{mg} \mathrm{C}$ $\mathrm{mg}^{-1} \mathrm{chl} \mathrm{h}^{-1}$ ), about 16 to $25 \%$ of PP in the 0 to $80 \mathrm{~m}$ water column is sufficient to support the BP either

Table 3. Linear regression statistics for various data sets. Variables are BP, PP (bacterial, primary production), IBP, IPP (integrated $\mathrm{BP}$ and PP), BB, PB (bacterial and phytoplankton biomass), BR (bacterial respiration), NPP (net PP)

\begin{tabular}{|c|c|c|c|c|c|c|c|c|c|}
\hline Source & Data & $\log (y), \log (x)$ & Unit & $\mathrm{n}$ & Slope & $\begin{array}{c}y^{-} \\
\text {intercept }\end{array}$ & $r^{2}$ & $\mathrm{p}$ & $\begin{array}{l}\text { Model II } \\
\text { slope }\end{array}$ \\
\hline This study & Group 1 & $\mathrm{BP}, \mathrm{PP}$ & $\mathrm{mgC} \mathrm{m}^{-3} \mathrm{~d}^{-1}$ & 18 & 0.56 & -0.35 & 0.72 & $<0.001$ & \\
\hline This study & Group 2 & $\mathrm{BP}, \mathrm{PP}$ & $\mathrm{mg} C \mathrm{~m}^{-3} \mathrm{~d}^{-1}$ & 15 & 0.60 & -0.44 & 0.52 & $<0.001$ & \\
\hline This study & All points & $\mathrm{BP}, \mathrm{PP}$ & $m g C m^{-3} d^{-1}$ & 32 & 0.57 & -0.39 & 0.68 & $<0.001$ & 0.64 \\
\hline Lochte et al. (1997) & Atlantic part, Southern Ocean & n $B P, P P$ & $\mathrm{mg} C \mathrm{~m}^{-3} \mathrm{~d}^{-1}$ & 34 & 0.71 & -0.16 & 0.63 & $<0.001$ & \\
\hline Cole et al. (1988) & Fresh, salt water & $\mathrm{BP}, \mathrm{PP}$ & $\mathrm{mgCm} \mathrm{m}^{-3} \mathrm{~d}^{-1}$ & 46 & 0.80 & -0.46 & 0.57 & $<0.001$ & \\
\hline Del Giorgio et al. (1997) & Unprod. systems & $B R, N P P$ & $\mathrm{mgCm} \mathrm{m}^{-3} \mathrm{~d}^{-1}$ & 47 & 0.34 & 1.21 & 0.30 & $<0.05$ & 0.62 \\
\hline This study & Fig. 6 & IBP, IPP & $\mathrm{mgC} \mathrm{m}^{-2} \mathrm{~d}^{-1}$ & 27 & 0.73 & 0.10 & 0.70 & $<0.001$ & 0.77 \\
\hline Cole et al. (1988) & Fresh, salt water & IBP, IPP & $\mathrm{mgC} \mathrm{m}^{-2} \mathrm{~d}^{-1}$ & 36 & 0.75 & 0.10 & 0.56 & $<0.001$ & \\
\hline This study & NW Mediterranean & IBP, IPP & $\mathrm{mmol} C \mathrm{~m}^{-2} \mathrm{~d}^{-1}$ & 11 & 0.62 & -0.11 & 0.73 & $<0.001$ & 0.52 \\
\hline This study & Fig. 6 & IBP, IPP & $\mathrm{mmol} \mathrm{C} \mathrm{m}^{-2} \mathrm{~d}^{-1}$ & 27 & 0.67 & -0.14 & 0.74 & $<0.001$ & 0.60 \\
\hline Hoch \& Kirchman (1993 & All points & IBP, IPP & minol $\mathrm{C} \mathrm{m}^{-2} \mathrm{~d}^{-1}$ & 240 & 0.37 & 0.70 & 0.30 & $<0.001$ & 0.68 \\
\hline (Delaware Estuary, & Coastal ocean & IBP, IPP & mmol $C \mathrm{~m}^{-2} \mathrm{~d}^{-1}$ & 80 & 0.65 & 0.11 & 0.50 & $<0.001$ & 0.92 \\
\hline \multirow{2}{*}{ NW Atlantic) } & Estuary & IBP, IPP & $\mathrm{mmol} \mathrm{C} \mathrm{m}^{-2} \mathrm{~d}^{-1}$ & 72 & 0.65 & 0.18 & 0.50 & $<0.001$ & 0.92 \\
\hline & River & IBP, IPP & 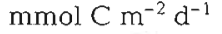 & 88 & 0.43 & 0.86 & 0.49 & $<0.001$ & 0.61 \\
\hline This study & NW Mediterranean & $\mathrm{BB}, \mathrm{PB}$ & $m g m^{-2}$ & 11 & 0.30 & 2.57 & 0.87 & $<0.001$ & 0.34 \\
\hline This study & NW Mediterranean & $\mathrm{BB}, \mathrm{PB}$ & $\mathrm{mg} \mathrm{m}^{-3}$ & 32 & 1.33 & -1.91 & 0.26 & $>0.10$ & \\
\hline Lochte et al. (1997) & Atlantic part, Southern Ocean & $\mathrm{BB}, \mathrm{PB}$ & $\mathrm{mg} \mathrm{C} \mathrm{m} \mathrm{m}^{-3}$ & 103 & 0.55 & -0.01 & 0.45 & $<0.001$ & \\
\hline Simon et al. (1992) & Fresh, salt water & $\mathrm{BB}, \mathrm{PB}$ & $\mathrm{mgC} \mathrm{m}^{-3}$ & 82 & 0.23 & 1.00 & 0.30 & $<0.001$ & \\
\hline
\end{tabular}



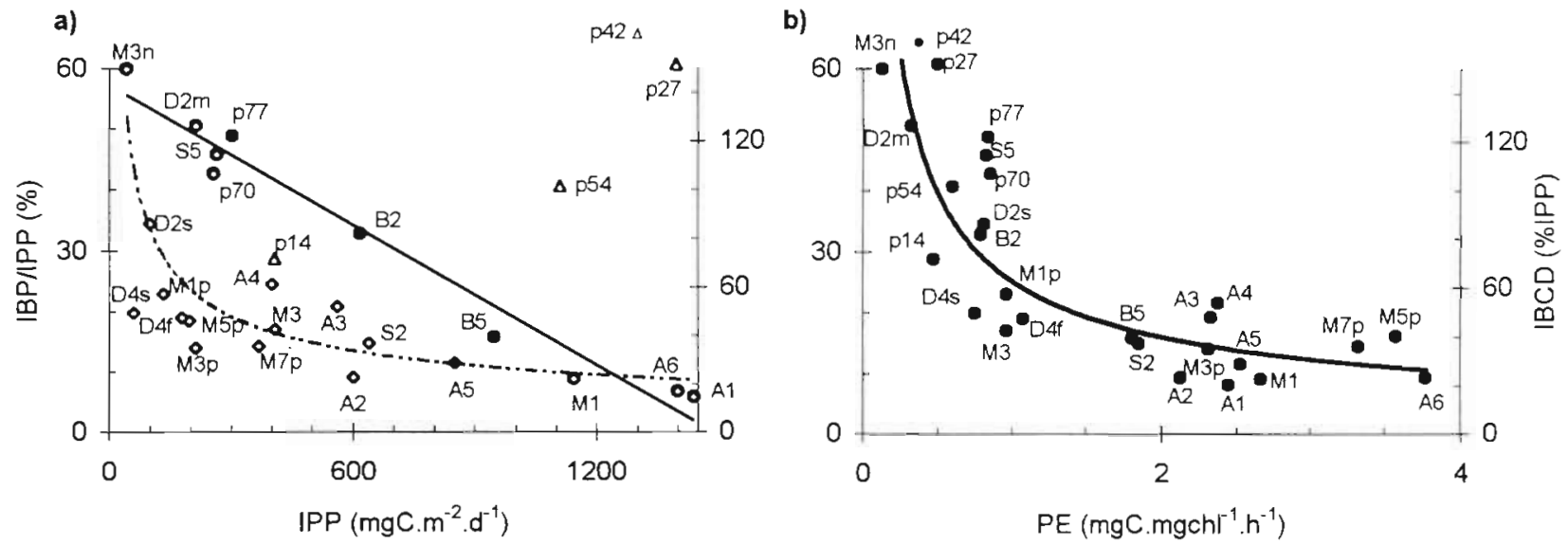

Fig. 6. (a) Plot of the ratio of IBP/IPP against IPP for all stations on the Euromarge cruise (as in Fig. 5) plus data from the Marseilles transect (M3n: November 1993; M1p, M3p, M5p and M7p: November 1994, Bianchi 1996); plus data off Crete in the eastern Mediterranean Sea: D2 and D4 in March (m), February (f) and September (s) 1995 (Van Wambeke et al. 1996, Psarra et al. 1996); plus data in the Alboran Sea A1 to A6 (Fernandez et al. 1994, Videau et al. 1994); plus data along the Algerian Current in the southwestern Mediterranean Sea: p14, p27, p42, p54, p70, p77 (Mediprod VI report). The new data fell into either or both of the relationships defined in Fig. 5, with the exception of stations indicated by $\Delta .(\diamond)$ Group $2\left(\mathrm{n}=20: \mathrm{IBP} / \mathrm{IPP}=336.7 \mathrm{IPP}{ }^{-0} 50, \mathrm{r}^{2}=0.57\right.$, $\mathrm{p} \leq 0.001$, or with a reduced major axis regression: IBP/IPP $\left.=882.5 \mathrm{IPP}-0.67, \mathrm{r}^{2}=0.57, \mathrm{p} \leq 0.001\right) .(\bullet)$ Group 1 ( $\mathrm{n}=10: \mathrm{IBP} / \mathrm{IPP}=$ $-0.04 \mathrm{IPP}+57.13, \mathrm{r}^{2}=0.97, \mathrm{p} \leq 0.001$, or, with a reduced major axis regression: IBP/IPP $\left.=-0.04 \mathrm{IPP}+57.50, \mathrm{r}^{2}=0.97, \mathrm{p} \leq 0.001\right)$. (b) Plot of IBP/IPP against the phytoplankton efficiency for the stations shown in Fig. 6a. The data no longer separate into 2 distinct groups and now best fit a power regression (IBP/IPP $=25.0 \mathrm{PE}^{-0.66}, \mathrm{r}^{2}=0.71, \mathrm{p} \leq 0.001$ or with a reduced major axis regression IBP/IPP $=25.1 \mathrm{PE}^{-0.68}, \mathrm{r}^{2}=0.71, \mathrm{p} \leq 0.001$ ). A second axis on the right shows equivalent estimates of integrated bacterial carbon demand (IBCD) expressed as percentage of IPP and is based on a carbon conversion efficiency of $40 \%$ (Bjørnsen \& Kuparinen 1991)

directly through phytoplankton release or indirectly through a range of other routes such as 'sloppy' feeding and release by zooplankton (Jumars et al. 1989), dissolution of faecal pellets, egestion of digestive vacuoles and cell lysis including lysis by viruses (Baines \& Pace 1991). On the other hand, when phytoplankton become less efficient (i.e. $\mathrm{PE} \leq 1.5 \mathrm{mg} \mathrm{C} \mathrm{mg}^{-1} \mathrm{chl} \mathrm{h}{ }^{-1}$ ), an increasing proportion of PP could be used by bacteria (Fig. 6b). To justify such a PP and BP coupling, the transfer of photosynthetic-derived material to bacteria must take place on a coherent time scale (i.e. hours to day).

\section{Short time-scale coupling between primary production and bacterial production}

The DOC pool can be divided into refractory, semilabile and highly labile pools (Billen \& Servais 1989). The highly labile pool (turnover from hours to days) represents a small percentage of the whole DOC pool (Kirchman et al. 1991). By assuming that only direct phytoplankton release and herbivory losses (due to heterotrophic nanoflagellate and ciliate grazing) constitute the main phytoplankton-derived labile DOC produced in the euphotic zone, we can estimate the contribution of these 2 sources in the BP/PP ratio (Table 4).
Excluding all methodological and biological artefacts, a mean of 10 to $14 \%$ of the total PP is directly released (Baines \& Pace 1991, Ducklow \& Carlson 1992). Assuming that bacteria grow on this released material with an efficiency of $40 \%$ (Bjørnsen \& Kuparinen 1991) or $50 \%$ (Coveney \& Wetzel 1989), bacterial assimilation represents 4 to $7 \%$ of PP (Table 4). Ducklow \& Carlson (1992) established that the DOM release by zooplankton could represent a maximum value of $25 \%$ of its ingestion. It is also recognised that PP could contribute from 22 to $100 \%$ of the total ingestion of heterotrophic nanoflagellates and ciliates (Rassoulzadegan et al. 1988, Ducklow \& Carlson 1992). Moreover, Christaki \& Van Wambeke (1995) obtained a growth bacterial efficiency of $34 \%$ on such a heterotrophic release material in an experimental microcosm. With such a yield, herbivory loss processes could represent 2 to $9 \%$ of PP (Table 4 ). So, the contribution of both direct DOC release by phytoplankton and herbivory losses to BP represents a range from 6 to $16 \%$ of PP. The percentages found at numerous stations (Fig. 6a) lie in this range, especially for those characterised by a PP higher than $400 \mathrm{mg} \mathrm{C} \mathrm{m} \mathrm{C}^{-2}$ or in Fig. $6 \mathrm{~b}$ for those characterised by a PE higher than $1.5 \mathrm{mg} \mathrm{C} \mathrm{mg}^{-1} \mathrm{chl} \mathrm{h}^{-1}$. This 6 to $16 \%$ range is in agreement with the estimation of 5 to $15 \%$ of the total net PP obtained experimentally by Fernandez et al. (1994) in the Mediterranean Sea. This is therefore an indication 
of the rapid processes fuelling BP from PP, i.e. processes which could justify a phytoplankton-bacteria coupling on a short time-scale (range from hours to day).

\section{Longer time-scale coupling between primary production and bacterial production}

In most cases, the grazing rate is not tightly coupled with the intensity of PP. Then, the algal cells lysis contribute to the pool of small suspending particulate organic matter (POM) and colloids (Ducklow et al. 1995). Bacteria are known to be one of the major contributors to the decomposition of POM to DOM through extraceliular enzyme production (Billen 1990, Hoppe 1991). Hydrolysis of senescent phytoplankton cells also contributes to the labile DOC pool as does the slower hydrolysis of the significant fraction of semilabile DOC (Carlson et al. 1996).

Low bacterial growth efficiencies ( 5 to $30 \%$ ) have been obtained in oligotrophic environments (Carlson \& Ducklow 1996) or even in most of the fresh- and marine water systems (10 to $25 \%$ ) (Del Giorgio et al. 1997 ) including the Mediterranean Sea (Sempéré et al. 1995). In such a case, bacterial carbon demand

Table 4 . Estimation of the potential contribution of both herbivory losses (right panel) and direct $\mathrm{DOC}$ release by phytoplankton (left panel) to bacterial production (see text for further details)

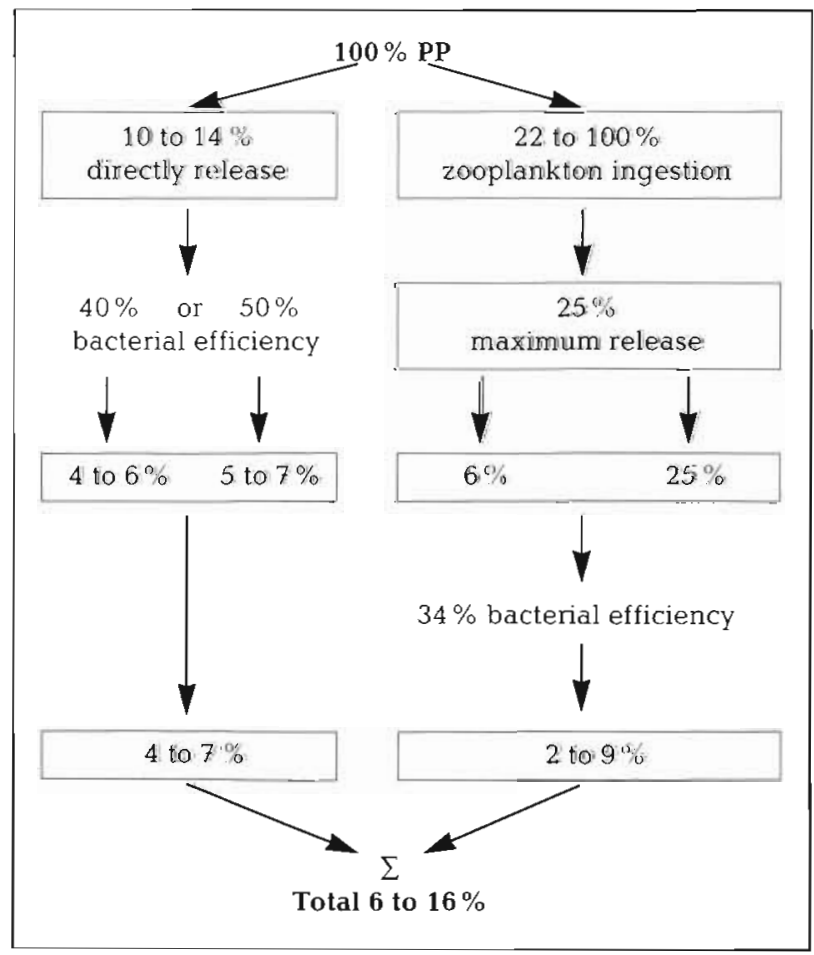

(Fig. 6a) can account for all or more than the concurrent estimates of PP (Carlson et al. 1996). This may be due to temporal and/or spatial variation in the supply of phytoplankton-derived material and bacterial uptake of DOC and/or to the variability of bacterial growth efficiency according to the DOC origin and size (Middleboe \& Sondergaard 1993, Carlson \& Ducklow 1996).

\section{Variability of phytoplankton efficiency}

Most of the stations characterised by a $\mathrm{PE}$ higher than 1.0 or $1.5 \mathrm{mg} \mathrm{C} \mathrm{mg}^{-1} \mathrm{chl} \mathrm{h}^{-1}$ (Fig. 6b) lie around the theoretical percentage found above for short-term linkage through release and grazing. Those stations with higher percentages (IBP/IPP up to $60 \%$ ) have a low $\mathrm{PE}$. The $\mathrm{PE}$ is known to vary between 0.1 and $35.0 \mathrm{mg} \mathrm{C} \mathrm{mg}^{-1} \mathrm{chl} \mathrm{h}^{-1}$ (cf. 'Introduction') but it generally lies in the range from 0.5 to $15.0 \mathrm{mg} \mathrm{C} \mathrm{mg}^{-1} \mathrm{chl} \mathrm{h}^{-1}$. Its variations are related to light and nutrient conditions (Schiewer 1984), to phytoplankton cell size (i.e. lower PE in smaller cells), and to water column stability and are therefore low in oligotrophic waters (Videau et al. 1994). The PE generally decreases with depth and from the beginning to the end of a spring bloom (Baamstedt 1985), and also during the summer (Le Bouteiller \& Herbland 1984). In the NW Mediterranean Sea, the PE lies from 0.1 to $7.0 \mathrm{mg} \mathrm{C} \mathrm{mg}^{-1} \mathrm{chl}$ $\mathrm{h}^{-1}$, with maximum values in April to June and minimum values at the end of the summer (Conan 1996).

The PE is known to characterise the potential of the chlorophyll pool to fix inorganic carbon. It roughly characterises the physiological state of the phytoplankton compartment. Finally, the PE could be considered as a good index of the trophic state of the system according to Falkowski \& Woodhead (1992). In this way in Fig. $6 \mathrm{~b}$, it is obvious that the distribution of the stations along the line of the power relationship characterises a relative richness, that is to say, an increasing oligotrophy from the right towards the left of the figure. Since the relationship between the IBP/IPP ratio and $\mathrm{PE}$ combines data throughout the year, from coastal and offshore stations and from greatly different geographical areas (NW and E Mediterranean), it can be viewed as an evolution of the relationship with time or with space. For example, Stn M3 (see Fig. 6b) exhibited the full range of the relationship between the IBP/IPP ratio and PE when sampled on 3 different occasions. Such variations indicate an evolution from mesotrophy to oligotrophy and vice versa, i.e. from autotrophic to heterotrophic system. This is in agreement with the results of the time series study carried out at this station (Conan 1996, Conan et al. 1998). There was also a decrease in the PE on an offshore 
(M7p and M5p) - inshore (M3p and M1p) transect during November, which reversed during July (M1 and M3).

\section{Biogeochemical significance of the power relationship}

A high proportion of PP could be released as DOM under oligotrophic or stress conditions and could then support a variable fraction of BP, which means a close coupling between phytoplankton release and bacterial uptake. In contrast, the contribution of PP to BP is reduced when there are allochthonous inputs of substrate or when phytoplankton growth is efficient (i.e. a weak proportion of PP is release as DOM). The biogeochemical consequence of a high BP/PP ratio is that there may be less material available for higher trophic levels of the marine foodweb and/or for export to the deeper ocean and benthos.

\section{Conclusion}

Despite the large variations in hydrodynamic, nutrient trophic status and biodiversity, on various time and space scales, there is a persistent significant relationship between the IBP/IPP ratio and PE. At higher PE, 10 to $25 \%$ of IPP is sufficient to support IBP in the euphotic zone. This percentage results essentially from direct phytoplankton release and grazing by zooplankton. These 2 processes are then sufficient to support bacterial growth if the efficiencies of 34 to $50 \%$ are valid with those DOM. However, at lower PE, the percentage of IPP needed to support IBP can increase up to $60 \%$. In those cases (and/or for lower bacterial efficiencies), other processes such as cell lysis, POM hydrolysis, external inputs of substrate by turbulent vertical diffusion and/or by advection presumably become increasingly important compared to direct phytoplankton release and grazing alone. This link between $\mathrm{BP}$ and the physiological state of the phytoplankton may explain the extremely wide range of IBP/IPP ratios previously found in other studies (see review of Ducklow \& Carlson 1992).

Acknowledgements. Our thanks to the officers and crew of the RV 'Suroit' and to X. Durrieu de Madron, who was lead scientist for this Euromarge cruise and supplied the CTD data reported here. This research was undertaken in the framework of the Mediterranean Targeted Project (MTP) - European Microbiology of Particulate Systems (EMPS) and EUROMARGE-NB projects, supported by the European Commission's Marine Science and Technology (MAST) Programme under contracts MAS2-CT94-0090 and MAS2-930053. Thanks to C. Videau, S. Psarra, M. Minas for providing some additional data used to demonstrate the relationship in
Fig. 6. Thanks also to P. Raimbault for assistance with the nutrient analysis, J. Harris for statistical advise, G. Ruddy for inspired discussion and $M$. Bianchi, whose coordination of the EMPS project facilitated this work. Finally we thank the reviewers for their comments which helped improve this manuscript.

\section{LITERATURE CITED}

Azam F, Fenchel T, Field JG, Gray JS, Meyer-Reil LA, Thingstad $F$ (1983) The ecological role of water-column microbes in the sea. Mar Ecol Prog Ser 10:257-263

Azam F, Smith DC, steward GF, Hagström \& (1993) Bacteriaorganic matter coupling and its significance for oceanic carbon cycling. Microb Ecol 28:167-179

Baamstedt U (1985) Spring-bloom dynamics in Kosterfjorden western Sweden: variation in phytoplankton production and macrozooplankton characteristics. Sarsia 70(1):69-82

Baines SB, Pace ML (1991) The production of dissolved organic matter by phytoplankton and its importance to bacteria: patterns across marine and freshwater systems Limnol Oceanogr 36:1078-1090

Bianchi M (1996) European microbiology of particulate systems. Final report, Vol I, Marseilles

Billen G (1990) Delayed development of bacterioplankton with respect to phytoplankton: a clue for understanding their trophic relationships. Arch Hydrobiol Beih Ergeb Limnol 34:191-201

Billen G. Servais P (1989) Modélisation des processus de dégradation bactérienne de la matière organique en milieu aquatique. In: Bianchi $M$, Marty D, Bertrand JC, Caumette P, Gauthier M (eds) Micro-organismes dans les écosystèmes océaniques. Masson, Paris, p 219-245

Bjornsen PK, Kuparinen J (1991) Determination of bacterioplankton biomass, net production and growth efficiency in the Southern Ocean. Mar Ecol Prog Ser 71:185-194

Bronk DA, Glibert PM, Ward BB (1994) Nitrogen uptake, dissolved organic nitrogen release, and new production. Science 265:1843-1846

Carlson CA, Ducklow HW (1996) Growth of bacterioplankton and consumption of dissolved organic carbon in the Sargasso Sea. Aquat Microb Ecol 10:69-85

Carlson CA, Ducklow HW, Sleeter TD (1996) Stocks and dynamics of bacterioplankton in the northwestern Sargasso Sea. Deep-Sea Res II 43:491-515

Chin-Leo G, Kirchman. DL (1988) Estimating bacterial production in marine waters from the simultaneous incorporation of thymidine and leucine. Appl Environ Microb 54: $1934-1939$

Christaki U, Van Wambeke F (1995) Simulated phytoplankton bloom input in top-down manipulated microcosms: comparative effect of zooflagellates, ciliates and copepods. Aquat Microb Ecol 9:137-147

Cole JJ, Findlay S, Pace ML (1988) Bacterial producion in fresh and saltwater ecosystems: a cross-system overview. Mar Ecol Prog Ser 43:1-10

Conan P (1996) Variabilité et bilan de la production primaire en zone côtière (Méditerranée Nord occidentale; entrée du golfe du Lion) en relation avec les systèmes biologique, chimique et hydrodynamique (Courant Nord Méditerranéen). PhD thesis, Université d'Aix-Marseille II

Conan P, Millot C (1995) Variability of the Northern Current in the Western Mediterranean Sea from February to June 1992. Oceanol Acta 18:193-205

Conan P, Pujo-Pay M, Raimbault P, Leveau M (1998) Variabilité spatio-temporelle des systèmes physique, chimique et 
biologique en Méditerranée Nord occidentale Igolfe du Lion) entre 1992 et 1994 . I. Flux de matière (N, P, chlorophylle) à travers une radiale Nord-Sud. II. Cycle et bilan de la productivité (14C) à la station centrale. Oceanol Acta 21(6):751-782

Copin-Montégut G, Avril B (1993) Vertical distribution and temporal variation of dissolved organic carbon in the North-Western Mediterranean Sea. Deep-Sea Res 40 $1963-1972$

Coveney MF, Wetzel RG (1989) Bacterial metabolism of algal extracellular carbon. Hydrobiologia 173:141-149

Dandonneau Y, Le Bouteiller A (1992) A simple and rapid device for measuring planktonic primary production by in situ sampling, and C14 injection and incubation. DeepSea Res 39:795-803

Del Giorgio PA, Cole JJ, Cimbleris A (1997) Respiration rates in bacteria exceed phytoplankton production in unproductive aquatic systems. Nature 385:148-151

Denman KL, Gargett AE (1983) Times and space scales of vertical mixing and advection of phytoplankton in the upper ocean. Limnol Oceanogr 28:801-815

Dillon TM, Caldwell DR (1980) The batchaloo spectrum and dissipation in the upper ocean spectrum. J Geophys Res 87:9601-9613

Ducklow HW, Carlson CA (1992) Oceanic bacterial production. Adv Microb Ecol 12:113-181

Ducklow HW, Purdie DA, Williams PJLeB, Davies JM (1986) Bacterioplankton: a sink for a carbon in a coastal marine plankton community. Science 232:865-867

Ducklow HW, Quinby HL, Carlson CA (1995) Bacterioplankton dynamics in the equatorial Pacific during the $1992 \mathrm{El}$ Niño. Deep-Sea Res II 42:621-638

Falkowski PG, Woodhead AD (1992) Primary productivity and biogeochemical cycles in the sea, Vol 43. Environmental Science Research, New York

Fernandez M, Bianchi M, Van Wambeke F (1994) Bacterial biomass, heterotrophic production and utilization of dissolved organic matter photosynthetically-produced in the Almeria-Oran front. J Mar Sys 5:313-325

Hoch MP, Kirchman DL (1993) Seasonal and inter-annual variability in bacterial production and biomass in a temperate estuary. Mar Ecol Prog Ser 98:283-295

Holm-Hansen O, Riemann B (1978) Chlorophyll a determination: improvements in methodology. Oikos 30:438-447

Hoppe HG (1991) Microbial extracellular enzyme activity: a new key parameter in aquatic ecology. In: Chrost RJ (ed) Microbial enzymes in aquatic environments. SpringerVerlag, New York, p 60-83

Jackson GA, Williams PM (1985) Importance of dissolved organic nitrogen and phosphorus to biological nutrient cycling. Deep-Sea Res 32:223-235

Jansson M (1988) Phosphate uptake and utilization by bacteria and algae. Hydrobiologia 170:177-185

Joiris C, Billen G, Lancelot C, Daro MH, Mommaerts JP, Bertels A, Bossicart M, Nijs J, Hecq JH (1982) A budget of carbon cycling in the Belgian coastal zone: relative roles of zooplankton, bacterioplankton and benthos in the utilization of primary production. Neth J Sea Res 16:260-275

Jørgensen NOG, Kroer N, Coffin RB, Yang XH, Lee C (1993) Dissolved free amino acids, combined amino acids, and DNA as sources of carbon and nitrogen to marine bacteria. Mar Ecol Prog Ser 98:135-148

Jumars PA, Penry DL, Baross JA, Perry MJ, Frost BW (1989) Closing the microbial loop: dissolved organic carbon pathway to heterotrophic bacteria from incomplete ingestion, digestion and absorption in animals. Deep-Sea Res 36 : $483-495$
Keller AA, Riebesell U (1989) Phytoplankton carbon dynamics during a winter-spring diatom bloom in an enclosed marine ecosystem: primary production, biomass and loss rates. Mar Biol 103:131-142

Kirchman D (1993) Leucine incorporation as a measure of biomass production by heterotrophic bacteria. In: Kemp PF, Sherr BF, Sherr EB, Cole JJ (eds) Handbook of methods in aquatic microbial ecology. Lewis Publishers, Boca Raton, p 509-512

Kirchman DL, Suzuki Y, Garside C, Ducklow HD (1991) High turnover rates of dissolved organic carbon during a spring phytoplankton bloom. Nature 352:612-614

Kirchman DL, Moss J, Keil RG (1992) Nitrate uptake by heterotrophic bacteria. Does it change the f-ratio? Arch Hydrobiol Beih Ergeb Limnol 37:129-138

Kirchman DL, Rich JH, Barber RT (1995) Biomass and biomass production of heterotrophic bacteria along $140^{\circ} \mathrm{W}$ in the Equatorial Pacific: effect of temperature on the microbial loop. Deep-Sea Res II 42:603-619

Larsson U, Hagström $\AA$ (1982) Fractionated phytoplankton primary production, exudate release and bacterial production in a Baltic eutrophication gradient. Mar Biol 67 $57-70$

Le Bouteiller A, Herbland A (1984) Carbon fixation and productivity index in relation to chlorophyll and light in the equatorial Atlantic Ocean. Oceanogr Trop 19:161-179

Lee S, Fuhrman JA (1987) Relationships between biovolume and biomass of naturally derived marine bacterioplankton. Appl Environ Microbiol 53:1298-1303

Lefèvre D, Minas HJ, Minas M, Robinson C, Williams PJLeB, Woodward EMS (1997) Review of gross community production, primary production, net community production and dark respiration in the gulf of Lions. Deep-Sea Res 44: $801-832$

Lochte K, Bjørnsen PK, Giesenhagen $\mathrm{H}$, Weber A (1997) Bacterial standing stock and production and their relation to phytoplankton in the Southern Ocean. Deep-Sea Res 44 321-340

Malinsky-Rushansky NZ, Legrand C (1996) Excretion of dissolved organic carbon by phytoplankton of different sizes and subsequent bacterial uptake. Mar Ecol Prog Ser 132 249-255

Mediprod VI Report (1991) Production pélagique de la Méditerranée Sud-occidentale (courant algérien). Mesures hydrologiques, chimiques et biologiques (Campagne Mediprod Vl, juin 1990). Campagnes Océanographiques Françaises (COF-IFREMER), Vol 16, Brest

Middelboe M, Sondergaard M (1993) Bacterioplankton growth yield: seasonal variations and coupling to substrate lability and $\beta$-glucosidase activity. Appl Environ Microb 59:3916-3921

Millot C (1987) Circulation in the western Mediterranean Sea Oceanol Acta 10:143-149

Minas HJ, Codispoti LA (1993) Estimation of primary production by observation of changes in the mesoscale nitrate field. ICES Mar Sci Symp 197:215-235

Myklestad S (1977) Production of carbohydrates by marine planktonic diatoms. II. Influence of the N/P ratio in the growth medium on the assimilation ratio, growth rate, and production of cellular and extracellular carbohydrates by Chaetoceros affinis var. willei (Gran) Hustedt and Skeletonema costatum (Grev) Cleve. J Exp Mar Biol Ecol 29 $161-179$

Parsons TR, Takahashi M, Hargave B (1984) Biological oceanic processes, 3rd edn. Pergamon Press, Oxford

Porter KG, Feig YS (1980) The use of DAPI for identifying and counting aquatic microflora. Limnol Oceanogr 25:943-948 
Psarra S, Tselepides A, Ignatiades L, Dafnomili E (1996) Primary production estimates in the Cretan Sea. In: Tselepides A, Papadopoulou KN, Polychronaki T (eds) Final report CINCS: pelagic-benthic coupling in the oligotrophic Cretan Sea. IMBC, p 46-53

Pujo-Pay M, Conan P, Raimbault P (1997) Excretion of dissolved organic nitrogen by phytoplankton assessed by wet oxidation and N-15 tracer procedures. Mar Ecol Prog Ser 153:99-111

Rassoulzadegan F, Laval-Peuto M, Sheldon RW (1988) Partitioning the food ration of marine ciliates between picoand nanoplankton. Hydrobiologia 159:75-88

Schiewer U (1984) In vitro primary productivity (phytoplankton efficiency) of phytoplankton from the Darss-Zingst estuary. Limnol Oceanogr 15:575-579

Sempéré $R$, Van Wambeke $F$, Arzoumanian $H$, Chambaud AL, Talbot V, Mazaudier D (1995) Biodegradability of dissolved and colloidal organic matter in Mediterranean waters. In: Bricaud A (ed) Structure and dynamics of oligotrophic ecosystems: evolution of concepts. JGOFS-France, Villefranche-sur-Mer, p 36-37

Sherr EB, Sherr BF, Albright LJ (1987) Bacteria: link or sink? Science 235:88-89

Simon M, Cho BC, Azam F (1992) Significance of bacterial biomass in lakes and ocean: comparison to phytoplankton biomass and biogeochemical implications. Mar Ecol Prog Ser 86:103-110

Steemann-Nielsen E (1951) Measurement of the production of the organic matter in the sea by mean of carbon 14 . Nature 167:684-685

Strickland JDH, Parsons TR (1972) A practical handbook of seawater analysis, 2nd edn. Bull Fish Res Board Can 167

Thingstad TF, Rassoulzadegan F (1995) Nutrient limitations, microbial food webs, and 'biological C-pumps': suggested

Editorial responsibility: William $L i$,

Dartmouth, Nova Scotia, Canada interactions in a P-limited Mediterranean. Mar Ecol Prog Ser 117:299-306

Tréguer P. Le Corre P (1975) Manuel d'analyses des sels nutritifs dans l'eau de mer. Laboratoire d'Océanographie Chimique Université de Bretagne Occidentale, Brest, p 110

Turley CM, Hughes DJ (1992) Effect of storage on direct estimates of bacterial numbers. Deep-Sea Res 39:375-394

Turley CM. Hughes DJ (1994) The effect of storage temperature on the enumeration of epifluorescence-detectable bacterial cells in preserved seawater samples. J Mar Biol Assoc UK 74:259-262

Turley CM, Stutt ED, Harris JRW, Ruddy G (1996) Final EMPS report from participant $n^{\circ}$ 5: Plymouth Marine Laboratory. In: Bianchi $M$ (ed) European Microbiology of Particulate Systems (EMPS) final report to the MAST II-Mediterranean Targeted Project, Vol II, Section 5, Marseilles

Van Wambeke F, Christaki U, Bianchi M (1996) Bacterial production estimates in the Cretan Sea. In: Tselepides $A$, Papadopoulou KN, Polychronaki T (eds) CINCS: pelagicbenthic coupling in the oligotrophic Cretan Sea. MTP Final Report, IMBC, Marseilles, p 59-67

Videau C, Sournia A, Prieur L, Fiala M (1994) Phytoplankton and primary production characteristics at selected sites in the geostrophic Almeria-Oran front system (SW Mediterranean Sea). J Mar Syst 5:235-250

Vosjan JH, Van Noort GJ (1998) Enumerating nucleoid-visible marine bacterioplankton: bacterial abundance determined after storage in formalin fixed samples agrees with isopropanol rinsing method. Aquat Microb Ecol 14: $149-154$

Wood AM, Van Valen LM (1990) Paradox lost? On the release of energy-rich compounds by phytoplankton. Mar Microb Food Webs 4(1):103-116

Submitted: February 14, 1998; Accepted: September 14, 1998 Proofs received from author(s): April 21, 1999 